\title{
Adaptability of Teff husk activated carbon for removal of hexavalent chromium from tannery wastewater at optimized process condition
}

\author{
Tsegaye Adane $^{1}$ [D $\cdot$ Awrajaw Dessie ${ }^{1}$
}

Received: 29 March 2020 / Accepted: 22 June 2020 / Published online: 1 August 2020

(c) The Author(s) 2020

\begin{abstract}
Tanneries are the major contributors to chromium pollution of the environment. Exposure to chromium (VI) can cause cancer, brain damage, central nervous dysfunction, blood composition damage; damage of lungs, kidneys, liver, and other vital organs. Although various studies have been done on the removal of $\mathrm{Cr}$ (VI) from synthetic wastewater, there is a lack of study in the adaptability of these methods in the treatment of real wastewater and expanding to the industrial application level. Therefore, the present study was aimed to examine the effectiveness of Teff husk activated carbon for the removal of $\mathrm{Cr}$ (VI) from tannery wastewater at optimized process conditions. The laboratory-based study was conducted to determine the $\mathrm{Cr}$ (VI) removal efficiency of Teff husk activated carbon from tannery wastewater. Data were entered and analyzed using SPSS version 20 statistical software. A paired sample $t$ test was also used to test the presence of a significant difference in the mean concentration of $\mathrm{Cr}(\mathrm{VI})$ before and after treatment of the wastewater with Teff husk activated carbon. Then $p$ value $<0.05$ was considered as a cutoff point for the presence of a mean significant difference. The removal efficiency was found to be $89.5 \%$. There was a significant difference in the mean concentration of $\mathrm{Cr}$ (VI) before and after treatment with Teff husk activated carbon with $a=956.899$ and $p$ value $<0.001$. This implies the Teff husk activated carbon was an efficient adsorbent for removal of hexavalent chromium from real wastewater. Column adsorption needs to be studied in the future.
\end{abstract}

Keywords Tannery $\cdot$ Wastewater $\cdot$ Chromium (VI) $\cdot$ Teff husk activated carbon

\section{Introduction}

Human activities that use water produce wastewater. Industrial wastes are generated from different processes and the amount and toxicity of waste released vary with its specific industrial processes (Belay 2010). According to the fourth World Water Development Report, only 20\% worldwide, $70 \%$ in high-income countries, and $8 \%$ in low-income countries of the wastewater generated get proper treatment before discharge to the environment (Sato et al. 2013). The potential of adverse impacts of industrial pollutants on water resources, human health, and the environment depends on the toxicity, mobility, and loading of the pollutants (Connor et al. 2017).

Tsegaye Adane

tseg729@gmail.com

1 Department of Environmental and Occupational Health and Safety, Institute of Public Health, College of Medicine and Health Sciences, University of Gondar, Gondar, Ethiopia
Tanneries are the major contributors to chromium pollution of the environment. Most tanneries in the world (about 90\%) use chromium salts to produce leather through the chrome tanning method, because these salts provide better leather flexibility, better water resistance, and a high shrinkage temperature. About $30 \%$ of initial chromium is not fixed by skins and remains in tanning liquor, which will be discharged as wastewater (Gebrekidan et al. 2009). The conventional chrome tanning may lead to 1500-3000 parts per million (ppm) of chromium in wastewater, whereas the recent chrome tanning method may also lead to the release of wastewater containing 500-1000 ppm of chromium (Dargo and Ayalew 2014). This is beyond the WHO tolerance limit for $\mathrm{Cr}$ (VI) to be discharged into inland surface water (0.1 ppm) (Kebede and Gashaw 2017). For instance, in India, about 2000-3000 tone of chromium discharges into the environment annually from tannery industries (Belay 2010).

In Ethiopia, there are more than 30 tannery industries in operation (Birhanie et al. 2017). They are the main source of chromium pollution of the environment (Birhanu 2014) and 
about 200-300 tone of chromium is estimated to be released into the environment annually from tannery industries (Amabye 2015). Most of the Ethiopian tanneries, including Bahir Dar tannery, use chrome tanning and discharges their wastewater to the nearby water bodies without adequate treatment. This may lead to the accumulation of chromium which has a significant adverse impact on aquatic flora and fauna, and public health. This can cause cancer, brain damage, central nervous dysfunction, blood composition damage; damage of lungs, kidneys, liver, and other vital organs (Abdel-Raouf and Abdul-Raheim 2017). In Ethiopia, the impact of water pollution from leather processing industries is already felt (Amabye 2015). The solution to this problem is highly significant to protect the aquatic ecosystem and human health ultimately. In recent years, the need for safe and economical methods for the removal of $\mathrm{Cr}$ (VI) from contaminated water has demanded research. Due to its inexpensiveness and efficient removal of metal ions, adsorption was identified as the best-suited method to be used in low-income countries such as Ethiopia for the removal of $\mathrm{Cr}$ (VI) from drinking and wastewater (Adane et al. 2020; Zhang et al. 2015; Desta 2013). Adsorption using activated carbons prepared from low-cost agricultural wastes such as sugarcane bagasse (Yogeshwaran and Priya 2017), Teff straw (Tadesse et al. 2015; Desta 2013), Rice husk (Mullick et al. 2018; Tripathi and Ranjan 2015; Hegazi 2013; Singh and Singh 2012), coffee husk (Berihun 2017; Teshome 2015), sawdust (Bulut and TEZ 2007), coconut shell (Devi et al. 2012), corncob (Tesfaye 2016), neem bark (Tripathi and Ranjan 2015) has been investigated for the elimination of $\mathrm{Cr}$ (VI) from wastewater. But most of them remain on trial with synthetic wastewater which doesn't contain competitive cations and matrices and less fitted to scale up to the industry level, and their adaptability to real industrial wastewater was not investigated. Teff (Eragrostis Teff) is a widely cultivated cereal crop mainly produced in Ethiopia and its husk is abundant, locally available, and low-cost agro-waste which can be used to prepare activated carbon for removal of $\mathrm{Cr}$ (VI) from contaminated wastewater (Adane et al. 2020; Tadesse et al. 2015; Desta 2013). From our previous study, Teff husk activated carbon (THAC) is effective for the removal of hexavalent chromium from synthetic wastewater, and the process parameters were optimized (Adane et al. 2020). Therefore this study was aimed to examine the effectiveness of THAC for removal of $\mathrm{Cr}$ (VI) from real industrial (tannery) wastewater with the presence of matrices at optimized process conditions. This is the best fit to scale up the technique to be applied at the industry level for the treatment of wastewater.

\section{Methods and materials}

\section{Study area, period, and design}

A laboratory-based experimental study was conducted at the University of Gondar from March to June 2018 Gondar, Ethiopia. The tannery wastewater was taken from Bahir Dar Tannery S.C., Bahir Dar, Ethiopia. In the city, two large tannery factories discharge their effluent to the Nile River without proper treatment and there is common chromium pollution of water bodies that is why the study has been conducted in this study area.

\section{Preparation of THAC}

Teff husk activated carbon was prepared from raw Teff husk (common agro-waste) using the chemical activation method by mixing with $1: 3 \mathrm{w} / \mathrm{w} \%$ of $\mathrm{H}_{2} \mathrm{SO}_{4}$. The detailed procedure used in the preparation of THAC is described in the article we published previously (Adane et al. 2020).

\section{Sample size determination and sampling procedures}

The sample size was determined by using an environmental sample size determination formula proposed by Manly Bryan ( 2008), by using the equation:

$n=\frac{4 \sigma^{2}}{\delta^{2}}$

where $n=$ Number of samples, $\sigma=$ standard deviation, $\delta=$ acceptable level of error.

Few samples were collected for pretest and the standard deviation $(\sigma)$ becomes 0.09 and taking an acceptable level of error $(\delta) 3.3 \%$, the total sample size to be taken was calculated and becomes 30 . Therefore, to determine the adaptability of the technique to industrial wastewater, 3 grab samples at a different time of a day at morning, midday and afternoon (at 3:00, 6:30 and 10:00 h) for 10 days in a month was taken from Bahir Dar Tannery effluent at the point of discharge of the wastewater.

$N=3$ samples $/$ day $\times 10$ days $=30$ samples.

\section{Characterization of tannery wastewater}

The samples of tannery wastewater were taken from Bahir Dar Tannery Share Company and characterized for its hexavalent chromium content, $\mathrm{pH}$, and temperature using the standard protocol to water and wastewater examination (APHA 2005). Hexavalent chromium was measured using 
a spectrophotometer; $\mathrm{pH}$ was also measured using digital $\mathrm{pH}$ meter after calibration with buffer solutions having a $\mathrm{pH}$ of $4.00,7.00$, and 10.00 . The temperature was also measured using a digital thermometer. Both $\mathrm{pH}$ and temperature were determined onsite.

\section{Application THAC to the treatment of industrial wastewater}

The adaptability of the technique enlarged with the Teff husk activated carbon for chromium (VI) removal was undertaken with some actual effluent samples. Chrome tanning effluent was collected from Bahir Dar Tannery at the discharge point.

\section{A sampling of wastewater}

$1000 \mathrm{ml}$ of wastewater composite sample was taken from Bahir Dar tannery effluent using polyethylene bottle which is cleaned with $10 \% \mathrm{v} / \mathrm{v} \mathrm{HNO}_{3}$ and rinsed with distilled water.

\section{Adsorption from wastewater}

The wastewater was treated with THAC at optimum conditions $(\mathrm{pH}=1.92$, adsorbent dose $=20.22 \mathrm{~g} / \mathrm{l}$, and contact time $=2.07 \mathrm{~h}$ ) with agitation speed of $200 \mathrm{rpm}$ at $25{ }^{\circ} \mathrm{C}$ (Adane et al. 2020). Then the samples were filtered using Whatman No.1 filter paper. Then the filtrate was digested for further analysis.

\section{Acid digestion of wastewater}

The digestion of wastewater for both treated with THAC and untreated samples was carried out by transferring a measured volume $(50 \mathrm{~mL})$ of well-mixed acid preserved water sample to a flask. Then $5 \mathrm{~mL}$ of concentrated $\mathrm{HNO}_{3}$ and a few boiling chips were added into the flask. The mixture was boiled and evaporated on a hot plate to the lowest volume possible (10 to $20 \mathrm{~mL}$ ). Heating and adding concentrated $\mathrm{HNO}_{3}$ have been continued as necessary until digestion becomes complete as shown by a light color clear solution. The sample doesn't allow to dry during digestion. Then the flasks were washed down with water and filtered. Then the filtrate was transferred into a $50-\mathrm{mL}$ volumetric flask and diluted to the mark and mixed thoroughly. A portion of this solution was taken for the required metal determinations (Berihun 2017).

\section{Oxidation of $\mathrm{Cr}$ (III) to $\mathrm{Cr}$ (VI)}

Since all forms of chromium in the effluent will be oxidized to $\mathrm{Cr}(\mathrm{VI})$ with different factors to cause environmental damage, determination of total chromium as hexavalent chromium is important. Therefore, $\mathrm{Cr}$ (III) was oxidized to $\mathrm{Cr}$
(VI) using a procedure reported elsewhere (Berihun 2017), by treating the portion of digested filtrate with strong oxidizing agents $\left(\mathrm{H}_{2} \mathrm{SO}_{4}\right.$ and $\left.\mathrm{KMnO}_{4}\right)$. Then total chromium to be discharged to the environment was determined as hexavalent chromium using UV-Vis spectrophotometer as follows.

\section{Analysis using UV-Vis spectrophotometer}

For analysis of hexavalent chromium in wastewater before and after treatment with THAC was analyzed using a UV-Vis spectrophotometer by carbazide method (Gebrekidan et al. 2009; Chasteen 1993). So the concentration of the residual $\mathrm{Cr}(\mathrm{VI})$ ion in the solution has been determined by microprocessor double beam UV-Vis spectrophotometer (PerkinElmer Spectrum65) at $540 \mathrm{~nm}$. A 25\% $\mathrm{w} / \mathrm{v}$ solution of diphenyl carbazide was prepared in $100 \mathrm{ml}$ acetone. Five milliliters of each of the sample solutions, containing various concentrations of $\mathrm{Cr}(\mathrm{VI})(0,2,4,6,8,10$, and $12 \mathrm{ppm}$ ) was pipetted out into $50-\mathrm{ml}$ standard volumetric flasks. To this $2 \mathrm{ml}$ of $3 \mathrm{MH}_{2} \mathrm{SO}_{4}$ was added following by $2 \mathrm{ml}$ of diphenyl carbazide and the total volume was made up to $50 \mathrm{ml}$ using distilled water. The solutions were allowed to stand 10 min before measurement. Chromium concentration estimated by the intensity of the color complex formed was measured using a microprocessor double beam UV-Vis spectrophotometer. The absorbance was measured against a reagent blank at a wavelength of $540 \mathrm{~nm}$ (Emirie 2015; Alfa-Sika et al. 2010). All samples were carried out in triplicate under the same conditions and the average results were taken. The percentage removal of $\mathrm{Cr}$ (VI) was calculated using the formula (Magoling and Macalalad 2017):

Removal efficiency $(\%)=\frac{\left(C_{o}-C_{t}\right)}{C_{o}} \times 100$

where $C_{o}$ and $C_{t}$ are the $\mathrm{Cr}(\mathrm{VI})$ concentrations in ppm initially and at a given time $t$, respectively.

\section{Data processing and statistical analysis}

Data were entered and analyzed using SPSS version 20 statistical software. For most variables, data were presented by frequencies and percentages. Descriptive analysis was done to present the mean and standard deviation of hexavalent chromium before and after treatment of the wastewater with THAC at optimized process conditions. A paired $t$ test was used to test the presence of a significant difference in mean hexavalent chromium concentration before and after treatment that shows the significant removal of $\mathrm{Cr}$ (VI) upon treatment with THAC. Then $p$ value $<0.05$ was considered as a cutoff point for the presence of a mean significant difference. Then the removal efficiency of THAC was determined by using the mean concentration of $\mathrm{Cr}(\mathrm{VI})$ before and after treatment. 


\section{Data quality control}

The chemical reagents in the study were standardized. The UV-Vis spectrophotometer was calibrated with seven standard solutions of hexavalent chromium $(0,2,4,6,8,10$, and $12 \mathrm{ppm}$ ). Then the calibration curve was drawn (absorbance vs concentration of $\mathrm{Cr}(\mathrm{VI})$ ) and the analysis of samples was performed when the correlation coefficient is greater than 0.99 (99\%) (“Appendix”). Reproducibility was also assured by triplicate each analysis and measurements. The recovery percent was also used as quality controls to evaluate the credibility of the method of digestion and measuring instruments.

\section{Results and discussion}

\section{Characterization of tannery wastewater and THAC}

From our previous study, THAC was already prepared, characterized, and optimized its application for the efficient removal of hexavalent chromium from synthetic wastewater. The process parameters including $\mathrm{pH}$, initial concentration of $\mathrm{Cr}(\mathrm{VI})$, adsorbent dose, and contact time were optimized using response surface methodology. The hexavalent chromium removal efficiency of THAC from synthetic wastewater was determined in the previous study (Adane et al. 2020). But in the most adaptable form, its application in real industrial wastewater treatment was in question. The mean $\mathrm{pH}$ of the effluent was $4.0 \pm 0.5$ and the mean temperature was also found to be $20.2 \pm 2.3{ }^{\circ} \mathrm{C}$. The mean concentration of chromium (VI) in the effluent was found to be $19.996 \mathrm{ppm}$ (Table 1). It was comparable with chromium (VI) concentration in tannery effluents in Bangladesh (Roy et al. 2018;

Table 1 Laboratory analysis results of actual wastewater samples taken from Bahir Dar Tannery SC, Ethiopia, 2019

\begin{tabular}{llc}
\hline Parameters & Number of samples & $\begin{array}{c}\text { Concentration } \\
(\text { mean } \pm \text { SD })\end{array}$ \\
\hline $\mathrm{Cr}(\mathrm{VI})(\mathrm{ppm})$ & 30 & $19.996 \pm 0.088$ \\
$\mathrm{pH}$ & 30 & $4.0 \pm 0.5$ \\
Temperature $\left({ }^{\circ} \mathrm{C}\right)$ & 30 & $20.2 \pm 2.3$ \\
\hline
\end{tabular}

$S D$ standard deviation
Kabir et al. 2017). It was also lower than hexavalent chromium concentration in effluents of Batu and Modjo tanneries (Hassen and Woldeamanuale 2017). It was much higher than the WHO recommended level of chromium (VI) to be discharged to the environment, which is $0.1 \mathrm{ppm}$ (Kebede and Gashaw 2017). This high discharge of hexavalent chromium is highly toxic to living organisms even at low concentration causing a carcinogenic effect (Dargo and Ayalew 2014). This is also indicated to the need for additional treatment to minimize toxic hexavalent chromium in the effluent be for discharged to the environment.

\section{Application of THAC onto real industrial wastewater}

Upon the treatment of effluent with THAC at optimized process conditions, the mean concentration of hexavalent chromium was decreased from $19.996 \mathrm{ppm}$ to $2.097 \mathrm{ppm}$ (Table 2 and Fig. 1). This is also found to be comparable with the national permitted limit of chromium concentration (2 ppm) for the tannery wastewater to be discharged directly to the environment. The THAC was better in its chromium removal efficiency as compared to the already existing treatment method. Therefore, it is advisable and better to use Teff husk activated carbon to treat the discharge effluents to reduce over $89.5 \%$ of toxic chromium and to protect the human health, aquatic ecosystem, and natural environment as a whole.

The paired $t$ test also revealed that there was a significant difference in the mean concentration of hexavalent chromium before and after treatment with THAC with $t=956.899$ and $p$ value $<0.001$ (Table 3). This implies the THAC was an efficient adsorbent for the removal of hexavalent chromium from real wastewaters and reduced the concentration at a significant level. The removal efficiency was found to be 89.5\%. This was consistent with other studies done using Biomass-based activated carbons as an adsorbent such as dried water hyacinth adsorbent (Kumar and Roy 2013), Gooseberry seed bio-sorbent (Aravind et al. 2016) and coffee husk activated carbon (Berihun 2017). It was found to have better efficiency than the other adsorbents such as Teff straw (Desta 2013). It was also less effective than other adsorbents such as Rice Husk activated carbon (Mullick et al. 2018), Prosopis Juliflora Plant activated carbon (Emirie 2015) and Bamboo activated carbon (Dula et al. 2014). These differences in removal efficiency may be due to the variation in

Table 2 Descriptive Statistics on the application of THAC as an adsorbent for removal of $\mathrm{Cr}$ (VI) and total Cr in real industrial wastewater with $\mathrm{pH} 2$, adsorbent dose of $2 \mathrm{~g} / 100 \mathrm{ml}$ of the solution, contact time $2 \mathrm{~h}, 200 \mathrm{rpm}$, and $25^{\circ} \mathrm{C}$

\begin{tabular}{llccrr}
\hline Conc. of $\mathrm{Cr}(\mathrm{VI})(\mathrm{ppm})$ & $N$ & Minimum & Maximum & Mean & Std. deviation \\
\hline Before treatment with THAC & 30 & 19.784 & 20.201 & 19.996 \\
After treatment with THAC & 30 & 1.952 & 2.259 & 2.097 & 0.088 \\
\hline
\end{tabular}




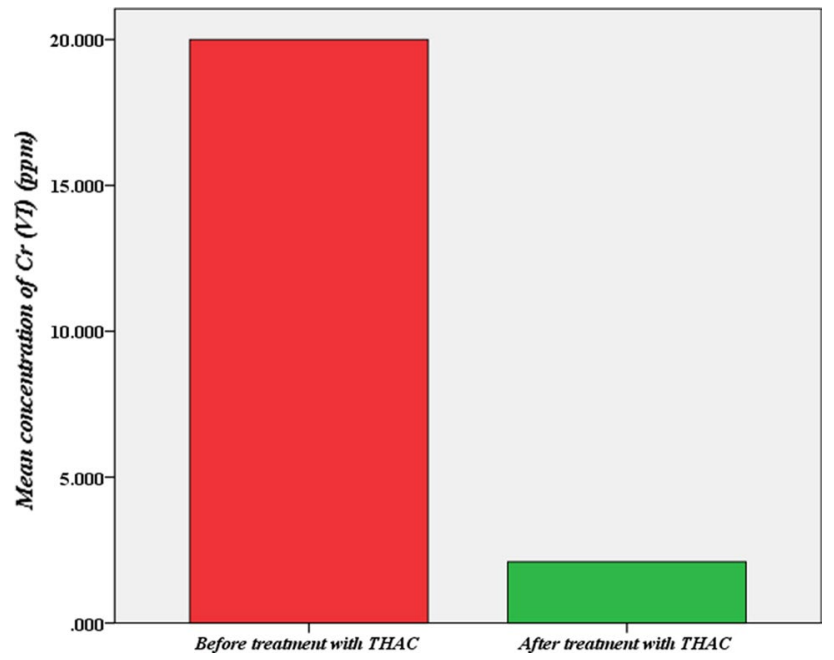

Fig. 1 concentration of hexavalent chromium in tannery effluent before and after treatment with THAC

the functional groups contained by adsorbents and the variation in the processes used for the preparation of adsorbents. The removal efficiency of THAC was also lower than its efficiency to remove hexavalent chromium from synthetic wastewater (Adane et al. 2020). This may be attributed to the presence of competitive ions and other matrices that lowers the removal efficiency of an adsorbent.

\section{The practical implication of using THAC for removal of $\mathrm{Cr}$ (VI)}

From the result of the current study, the application of Teff husk activated carbon on real industrial wastewater can remove above $89.5 \%$ of hexavalent chromium. This depicts that it can capable of reducing the diseases and environmental damages caused by chromium pollution with a significant amount, and can be used as a preventive measure to protect human health and health of the environment. The industries should also develop a habit to use THAC for the removal of toxic chromium from industrial wastewater for the protection of human health and the environment.

\section{Recovery percent as quality control}

The recovery percent was used as quality controls to evaluate the effectiveness of the method of digestion and measuring instruments. The recovery percent was found to be about $95.35 \%$ (Table 4). This implies that the method of digestion and measuring instruments were able to retain $95.35 \%$ of hexavalent chromium that exist in the sample; only $4.65 \%$ may be missed and lost during digestion. Therefore result from this experiment is confirmed to be accurate, and the data generated were credible.

\section{Limitation of the study}

In this study the adsorption was conducted in batch adsorption manner due to the short period of the study, so the adsorption is not conducted in the column adsorption process which is better fit to design in industries. Since the sample is taken from one industry, it might not show the nature of tannery wastewater in Ethiopia.

\section{Conclusion and recommendation}

In conclusion, Teff husk activated carbon can be used as an effective, locally available, low cost, and environmentally friendly adsorbent for the removal of chromium (VI) from contaminated water. Since real industrial wastewater doesn't contain a single heavy metal, the competitive effect of other heavy metals on the Cr (VI) removal efficiency of Teff husk activated carbon should be studied. Once used up, the Teff husk activated carbon, the regeneration mechanism also needs further study.
Table 3 Paired sample t-test result on application of THAC as an adsorbent for removal of $\mathrm{Cr}$ (VI) in real industrial wastewater with $\mathrm{pH} 1.92$, adsorbent dose of $2.02 \mathrm{~g} / 100 \mathrm{ml}$ of the solution, contact time $2.07 \mathrm{hrs}, 200 \mathrm{rpm}$, and $25^{\circ} \mathrm{C}$

Table 4 Recovery tests for the optimized procedure of wastewater sample

\begin{tabular}{|c|c|c|c|c|c|c|c|}
\hline \multicolumn{8}{|c|}{$\mathrm{Cr}(\mathrm{VI})$ before treatment $-\mathrm{Cr}(\mathrm{VI})$ after treatment } \\
\hline \multicolumn{5}{|c|}{ Paired differences } & \multirow[t]{3}{*}{$t$} & \multirow[t]{3}{*}{$d f$} & \multirow[t]{3}{*}{ Sig. (2-tailed) } \\
\hline \multirow[t]{2}{*}{ Mean } & \multirow[t]{2}{*}{ Std. deviation } & \multirow[t]{2}{*}{ Std. error mean } & \multicolumn{2}{|c|}{$95 \%$ CI of difference } & & & \\
\hline & & & Lower & Upper & & & \\
\hline 17.899 & 0.102 & 0.019 & 17.861 & 17.937 & 956.899 & 29 & .000 \\
\hline
\end{tabular}

\begin{tabular}{lclll}
\hline Sample & $\begin{array}{l}\text { Conc. in unspiked } \\
\text { sample }(\mathrm{ppm})\end{array}$ & $\begin{array}{l}\text { Amount } \\
\text { added }(\mathrm{ppm})\end{array}$ & $\begin{array}{l}\text { Conc. in spiked } \\
\text { sample }(\mathrm{ppm})\end{array}$ & Mean \% recovery \\
\hline Untreated effluent & $19.996 \pm 0.086$ & 2.0 & $22.06 \pm 0.088$ & 95.35 \\
Effluent treated with THAC & $2.097 \pm 0.048$ & 2.0 & $4.005 \pm 0.048$ & \\
\hline
\end{tabular}


Acknowledgements The authors are pleased to acknowledge the University of Gondar for its unreserved contribution to the success of this study.

Author contributions TA: prepare the tools, conduct experimental analysis, analyze and interpret the data, and write up the manuscript. AD: Advice throughout the process. All authors read and approved the final manuscript.

Funding This research did not receive any specific grant from funding agencies in the public, commercial, or not-for-profit sectors.

\section{Compliance with ethical standards}

Ethical approval Ethical approval was obtained from the Institutional Review Board of Institute of Public Health, University of Gondar. Chrome tanning effluent samples were also collected from Bahir Dar tannery after getting appropriate permissions and oral consent from the responsible authorities.

Conflict of interest The authors declare that they have no conflict of interest.

Consent for publication All authors read and approved the manuscript.

Open Access This article is licensed under a Creative Commons Attribution 4.0 International License, which permits use, sharing, adaptation, distribution and reproduction in any medium or format, as long as you give appropriate credit to the original author(s) and the source, provide a link to the Creative Commons licence, and indicate if changes were made. The images or other third party material in this article are included in the article's Creative Commons licence, unless indicated otherwise in a credit line to the material. If material is not included in the article's Creative Commons licence and your intended use is not permitted by statutory regulation or exceeds the permitted use, you will need to obtain permission directly from the copyright holder. To view a copy of this licence, visit http://creativecommons.org/licenses/by/4.0/.

\section{Appendix}

See Table 5 and Fig. 2.

Table 5 Calibration curve for $\mathrm{Cr}$ (VI) measurement using UV-VIS spectrophotometer

\begin{tabular}{ll}
\hline Conc. of standards $(\mathrm{mg} / \mathrm{L})$ & Mean absorbance $(\%)$ \\
\hline 0 & 0 \\
2 & 0.001 \\
4 & 0.001667 \\
6 & 0.003 \\
8 & 0.004 \\
10 & 0.005 \\
12 & 0.006 \\
\hline
\end{tabular}

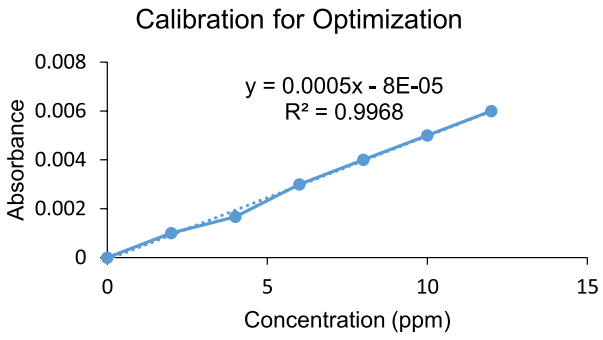

Fig. 2 Calibration curve for $\mathrm{Cr}(\mathrm{VI})$ measurement

\section{References}

Abdel-raouf M, Abdul-raheim A (2017) Removal of heavy metals from industrial waste water by biomass-based materials: a review. J Pollut Effects Control 5(1):1-13

Adane T, Haile D, Dessie A, Abebe Y, Dagne H (2020) Response surface methodology as a statistical tool for optimization of removal of chromium (VI) from aqueous solution by Teff (Eragrostis teff) husk activated carbon. Appl Water Sci 10(1):1-13

Alfa-sika MS-L, Liu F, Chen H (2010) Optimization of key parameters for chromium (VI) removal from aqueous solutions using activated charcoal. J Soil Sci Environ Manag 1(3):55-62

Amabye TG (2015) Plant, soil and water pollution due to tannery effluent a case study from Sheb Tannery PLC, Wukro Tigray, Ethiopia. Science 3(5):47-51

Apha (2005) Standard methods for the examination of water and wastewater. American Public Health Association (APHA), Washington, DC

Aravind J, Kanmani P, Sudha G, Balan R (2016) Optimization of chromium (VI) biosorption using gooseberry seeds by response surface methodology. Glob J Environ Sci Manag 2(1):61-68

Belay AA (2010) Impacts of chromium from tannery effluent and evaluation of alternative treatment options. J Environ Protect 1(01):53

Berihun D (2017) Removal of chromium from industrial wastewater by adsorption using coffee husk. J Mater Sci Eng 6(2):331

Birhanie M, Leta S, Khan MM (2017) Removal of hazardous pollutants from tannery wastewater by naval filter medium (pumice) through adsorption and filtration method. IOSR J Environ Sci Toxicol Food Technol IOSR-JESTFT 11(9):2319

Birhanu A (2014) Technology, performance and design evaluation of tannery wastewater treatment plants in the vicinity of Addis Ababa, Ethiopia (The Case of China Africa Tannery). Addis Ababa University, Addis Ababa

Bulut Y, Tez Z (2007) Removal of heavy metals from aqueous solution by sawdust adsorption. J Environ Sci 19(2):160-166

Chasteen TG (1993) Qualitative and instrumental analysis of environmentally significant elements. Wiley, Amsterdam

Connor R, Renata A, Ortigara C, Koncagül E, Uhlenbrook S, Lamizana-Diallo BM, Zadeh SM, Qadir M, Kjellén M, Sjödin J (2017) The united nations world water development report 2017. wastewater: the untapped resource. The United Nations World Water Development Report

Dargo H, Ayalew A (2014) Tannery waste water treatment: a review. Int J Emerg Trends Sci Technol 1(9):1488-1494

Desta MB (2013) Batch sorption experiments: Langmuir and Freundlich isotherm studies for the adsorption of textile metal ions onto teff straw (Eragrostis tef) agricultural waste. J Thermodyn

Devi BV, Jahagirdar A, Ahmed MZ (2012) Adsorption of chromium on activated carbon prepared from coconut shell. Int J Eng Res Appl 2(5):364-370 
Dula T, Siraj K, Kitte SA (2014) Adsorption of hexavalent chromium from aqueous solution using chemically activated carbon prepared from locally available waste of bamboo (Oxytenanthera abyssinica). ISRN Environ Chem

Emirie M (2015) Removal of chromium hexavalent (Cr (VI) from aqueous solution using activated carbon prepared from Prosopis Juliflora Plant and find the optimal operating condition for adsorption process. Addis Ababa University, Addis Ababa

Gebrekidan A, Gebresellasie G, Mulugeta A (2009) Environmental impacts of Sheba tannery (Ethiopia) effluents on the surrounding water bodies. -Bull Chem Soc Ethiopia 23(2)

Hassen AS, Woldeamanuale TB (2017) Evaluation and Characterization of Tannery Wastewater in each process at batu and modjo tannery, Ethiopia. Int J Environ Sci Nat Res 8(2):555732

Hegazi HA (2013) Removal of heavy metals from wastewater using agricultural and industrial wastes as adsorbents. HBRC J 9(3):276-282

Kabir MM, Fakhruddin A, Chowdhury M, Fardous Z, Islam R (2017) Characterization of tannery effluents of Hazaribagh area, Dhaka, Bangladesh. Pollution 3(3):395-406

Kebede F, Gashaw A (2017) Removal of chromium and azo metalcomplex dyes using activated carbon synthesized from tannery wastes. Open Access J Sci Technol 5(2):1-30

Kumar KS, Roy S (2013) Adsorption of hexavalent chromium from aqueous solution by water hyacinth (eichhornia crassipes). Development 25:27

Magoling BJA, Macalalad AA (2017) Optimization and response surface modelling of activated carbon production from Mahogany fruit husk for removal of chromium (VI) from aqueous solution. BioResources 12(2):3001-3016

Manly Bryan F (2008) Statistics for environmental science and management. Chapman and Hall/CRC, New York

Mullick A, Moulik S, Bhattacharjee S (2018) Removal of hexavalent chromium from aqueous solutions by low-cost rice husk-based activated carbon: kinetic and thermodynamic studies. Indian Chem Eng 60(1):58-71

Roy C, Jahan M, Rahman S (2018) Characterization and treatment of textile wastewater by aquatic plants (macrophytes) and algae. Eur J Sustain Dev Res 2(3):29

Sato T, Qadir M, Yamamoto S, Endo T, Zahoor A (2013) Global, regional, and country level need for data on wastewater generation, treatment, and use. Agric Water Manag 130:1-13

Singh S, Singh A (2012) Treatment of water containg chromium (VI) using rice husk carbon as a newlow cost adsorbent

Tadesse B, Teju E, Megersa N (2015) The Teff straw: a novel low-cost adsorbent for quantitative removal of $\mathrm{Cr}$ (VI) from contaminated aqueous samples. Desalin Water Treat 56(11):2925-2936

Tesfaye D (2016) Removal of lead from waste water using corn cob activated carbon as an adsorbent. Addis Ababa University, Addis Ababa

Teshome A (2015) Preparation, characterization and application of coffee husk based activated carbon for adsorption of $\mathrm{Cr}$ (VI) from aqueous solution. Addis Ababa University, Addis Ababa

Tripathi A, Ranjan MR (2015) Heavy metal removal from wastewater using low cost adsorbents. J Bioremed Biodegrad 6(06):1-5

Yogeshwaran V, Priya A (2017) Removal of hexavalent chromium (Cr6) using different natural adsorbents-a review. Available at SSRN 3090245

Zhang J, Shang T, Jin X, Gao J, Zhao Q (2015) Study of chromium (VI) removal from aqueous solution using nitrogen-enriched activated carbon based bamboo processing residues. RSC Adv 5(1):784-790

Publisher's Note Springer Nature remains neutral with regard to jurisdictional claims in published maps and institutional affiliations. 